Animal Health Reasearch Laboratory, Assiut.

\title{
DETECTION AND ENUMERATION OF LISTERIA MONOCYTOGENES IN MINCED BEEF AND LIVER IN ASSIUT GOVERNORATE
}

(With 2 Tables)

\author{
By \\ A. A. ABOU EL-ALLA and A. M. SAYED
}

(Received at 16/2/1999)

\section{اكتثاف وعد ميكروب الليستريا مونوسيتوجينز فى اللحوم المفرومة والكبله في محافظة أسيوط مونوسينز}

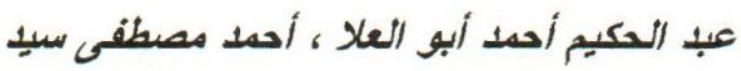

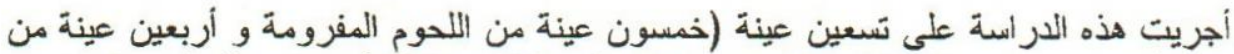

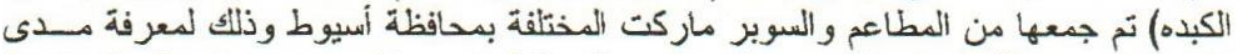

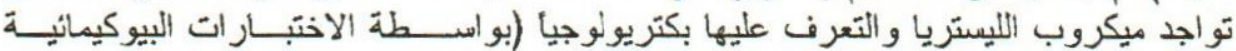

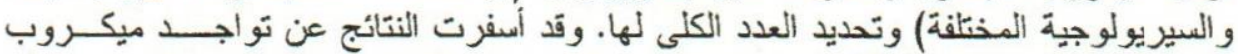

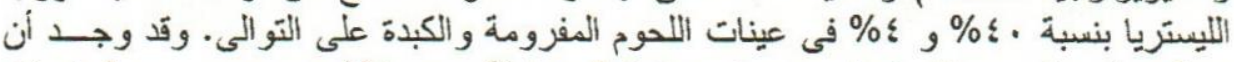

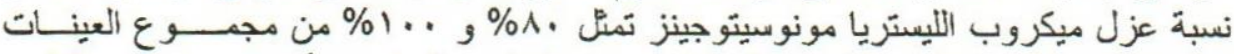

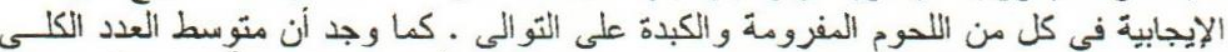

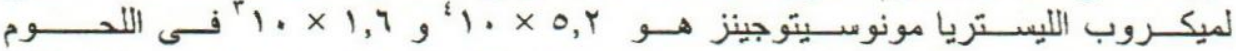

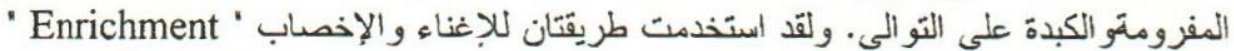

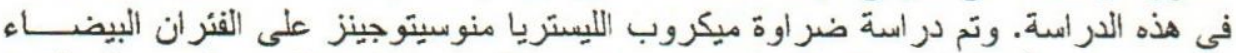

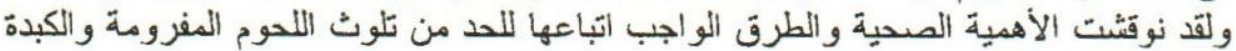
بهذا الميكروب نو الأن

\section{SUMMARY}

A total of ninety samples (50 of minced beef and 40 of liver) were collected from randomly selected supermarkets and restaurant at Assiut city and examined for the presence of Listeria spp. Listeria spp. was detected in $40 \%$ and $4 \%$ of both minced beef and liver respectively. L. monocytogenes was recovered from $80 \%$ and $100 \%$ of the all positive samples of both minced beef and liver. The average number of colony 
forming unit/gram (CFU/g) of L.monocytogenes were $5.2 \times 10^{4}$ and 1.6 $\mathrm{X} 10^{3}$ in both minced beef and liver respectively. Two methods of the enrichment for the isolation of Listeria spp. were performed. Pathogenicity of L. monocytogenes to mice was studied. The public health importance as well as recommended sanitary measures were discussed.

Key words: Listeria Monocytogenes, Minced.

\section{INTRODUCTION}

The role and importance of Listeria monocytogenes as an agent of foodborne disease is becoming increasingly apparent. L. monocytogenes, which is pathogenic for both humans and animals, can cause abortion and mastitis in demostic animals (Gitter et al. , 1980), abortion in pregnant women and often fatal (30\% mortality) meningitis and encephalitis in newborn infants and immunocompromised adults (Hyslop, 1974). This pathogen can be transmitted from infected animal to humans (Odegaard et al., 1952) and also can be transmitted to human through consumption of food of animal origin.

Meat and meat products have frequently been found to be contaminated with L. monocytogenes (Johnson et al., 1988) and may serve as vehicles of this pathogenic bacterium. The frequent occurrence of L. monocytogenes and its ability to survive and proliferate at refrigeration temperatures provokes accumulation of this pathogen in contaminated meat products during cold storage, and hence presents a potential risk for consumers (Doyle, 1988).

L. monocytogenes is an ubiquitous organism. It can be shed from intestine of animals and man without any apparent symptoms (Gracey and Collins, 1992). Hence, the presence of the organism during the processing of meat products become unavoidable (Lowry and Tiong, 1988).

Although L. monocytogenes are found in meat and meat products, there is relatively little published infromation on the number of this organism (Johnson et al., 1990). Therefore, the main aim of the present study was to obtain information on the incidence of contamination and number of L. monocytogenes in both minced beef and liver at Assiut Governorate by using two methods of enrichmnet prior to isolation. 


\section{MATERIAL and METHODS}

\section{Sampling:}

Ninety (90) samples (fifty samples of minced beef and forty samples of liver) were collected from randomly selected supermarkets and restaurants at Assiut Governorate and represented various meat plants. Each sample was wrapped separately and aseptically in sterile polyethylene bag, then labelled and transferred under refrigeration (2$7^{\circ} \mathrm{C}$ ) as quickly as possible to the laboratory where isolation and enumeration procedures were performed.

Enumeration and isolation of L. monocytogenes:

Within $2 \mathrm{~h}$. of purchase, $25 \mathrm{~g}$ of each sample was blended in 225 $\mathrm{ml}$ (1:10 dilution) of sterile Listeria selective enrichment broth (LSEB, Oxid) using sterile blender at high speed for $3 \mathrm{~min}$. Serial 10- fold dilutions in $0.1 \%$ peptone water from all samples (from $10^{-1}$ to $10^{-7}$ ) were made and by surface plating techniques, $0.1 \mathrm{ml}$ from each dilution was transferred and evenly spread over dry surface of Listeria selective agar (Oxford formulation, Oxid) (LSA) and incubated at $37^{\circ} \mathrm{C}$ for $48 \mathrm{~h}$. The residual suspension was also incubated at $30^{\circ} \mathrm{C}$ for $48 \mathrm{~h}$. to determine the presence of Listeria. After incubation, one loopful was subcultured on LSA and incubated at $37^{\circ} \mathrm{C}$ on $24 \mathrm{~h}$. (Frederick, and Vanderlinde 1992). Presumptive colonies (Listeria hydrolyzes aesculin, producing black zones around the colonies on LSA) were picked on tryptone soya agar supplemented with $0.2 \%$ yeast extract and $0.2 \%$ glucose (TYSG), incubated at $30^{\circ} \mathrm{C}$ for $24 \mathrm{~h}$. and confirmed according to Seeliger and Jones (1986), through Gram staining reaction (+) oxidase (-), catalase $(+)$, motility at $21^{\circ} \mathrm{c}$ in motile agar media (+umbrella top shape), Urease(ve) and Kliger iron agar (+glucose and Lactose fermentation without gas and -ve hydrogen sulphide production). Confirmed colonies of Listeria were further identified into species through detection of $\beta$-.heamolysis on $5-10 \%$ sheep blood agar, carbohydrate fermentation and nitrate reduction (Quinn et al.,1994).

Serological slide agglutination test was done on all isolates thought to be L.monocytogenes using commerically prepared antiserum (Difco) O poly 2302-50-0 (antiserum contain agglutinins for all serotypes of L.monocytogenes). 
All initial samples diluted in 225 LSEB from which Listeria were not isolated, were re-examined after $2,4,6$ and 8 weeks of storage at $3^{\circ} \mathrm{C}$ or until Listeria was detected. Cold-enrichment samples were surface plated on LSA plates and incubated $48 \mathrm{~h}$ at $37^{\circ} \mathrm{C}$. Colonies resembling Listeria were confirmed as previously described (Ryser et $\underline{\text { al, }}$ 1985).

Pathogenicity test (Seeliger and Jones 1986):

All isolates confirmed as L. monocytogenes were grown over night at $30^{\circ} \mathrm{C}$ in $10 \mathrm{ml}$ of LSEB, centrifuged and pellet was resuspended in $1 \mathrm{ml}$ physological saline. Swiss white mice weighting 16-20 gm were each inoculated $\mathrm{I} / \mathrm{P}$ with $0.1 \mathrm{ml}$ of bacterial suspension. The inoculated mice was maintained under observation for evaluation of clinical signs and mortalities. The dead mice were scarified and the liver, spleen and brain were collected and processed for L.monocytogenes isolation using LSEB and LSA.

\section{RESULTS}

The obtained results were recorded in Tables 1 and 2 .

Table 1: Numbers and percentage of Listeira spp. recovered from minced beef and liver by using two enrichment methods.

\begin{tabular}{|c|c|c|c|c|c|}
\hline Samples & $\begin{array}{c}\text { No. of } \\
\text { examined } \\
\text { samples }\end{array}$ & $\begin{array}{l}\text { L. moncyto- } \\
\text { genes }\end{array}$ & L.innocua & $\begin{array}{l}\text { L.wels- } \\
\text { himeri }\end{array}$ & $\begin{array}{c}\text { Total } \\
\text { listeria spp }\end{array}$ \\
\hline $\begin{array}{l}\text { Minced beef. } \\
\text {-Incubated at } \\
30^{\circ} \mathrm{C} \text { for } 48 \mathrm{~h} \text {. } \\
\text {-After cold } \\
\text { enrichment }\end{array}$ & 50 & $6(12 \%)$ & $1(2 \%)$ & $1(2 \%)$. & $\begin{array}{l}8(16 \%) \\
12(24 \%)\end{array}$ \\
\hline Total & & $16(32 \%)$ & $3(6 \%)$ & $1(2 \%)$ & $20(40 \%)$ \\
\hline $\begin{array}{l}\text { Liver } \\
\text {-Incubated at } \\
30^{\circ} \mathrm{C} \text { for } 48 \mathrm{~h} \text {. } \\
\text {-After cold } \\
\text { enrichment. }\end{array}$ & 40 & $2(5 \%)$ & - & - & $2(5 \%)$ \\
\hline Total & 90 & 2. $(5 \%)$ & & & $2(5 \%)$ \\
\hline
\end{tabular}


Table 2: Number of L. monocytogenes (CFU/g) in positive samples of minced beef and liver

\begin{tabular}{||l|c|c|c|}
\hline \multicolumn{1}{|c|}{ Samples } & Minimum & Maximum & Average \\
\hline - Minced beef & $2 \times 10^{3}$ & $6.3 \times 10^{6}$ & $5.2 \times 10^{4}$ \\
- Liver* & $2.1 \times 10^{2}$ & $2 \times 10^{4}$ & $1.6 \times 10^{3}$ \\
\hline
\end{tabular}

* Counted after cold enrichment.

\section{DISCUSSION}

Foodborne listeriosis nowday is represented a serious public health problem in many countries since the fatality rate is high (ICMSF, 1996).

In this study Listeria spp. was detected in $40 \%$ and $4 \%$ of the minced beef and liver respectively,obtained from different supermarkets and restaurants over 4 months period at Assiut city (Table 1). These obtained results were in agreement with recent surveys who found that the prevalence of Listeria in minced meat and other products requiring cooking before consumption ranged from 8 to $92 \%$ (Johnson et at, 1990,Grau and Vanderlinde 1992, and El-Gazzar and Sallam, 1997). Höhne et al. (1975) isolated L.monocytogenes by cold enrichment from 8 of, 342 liver and intestinal lymph nodes samples of apparently healthy slaughter animals, while Temper (1961) failed to isolate Listeria spp. from 331 liver, spleen and kidney samples.

In this study, it was observed that higher incidence of Listeria spp. on minced beef samples $(40 \%)$ than on liver samples (4\%) (Table 1). This is mainly due to suggesting contamination of minced beef by cutting boards, knives, other work surfaces, additional processing steps and human contact during preparation of such product in restaurants (Lowry and Tiong, 1988, and Kerr et.al. 1993).

Results given in Table (1) point out that L.monocytogenes was detected more frequently in both minced beef $(80 \%, 16 / 20)$ and liver $(100 \% 2 / 2)$ than other Listeria spp. Similar finidings were reported by Luppi et at. (1988) and Grau, and Vanderlinde, (1992). On the other hand Breer and Schopfer (1988) recorded that the isolation of L.innocua from meat and meat products was common, and often the incidence of this organsim was higher than that of L.monocytogenes. This species differences may be attributed to differences in geographic distribution of 
Listeria, variation in animal husbandry and feeding practices or variation in methods of isolation (WHO 1988).

The data presented in Table (1) shows that $(14 / 22)$ of all positive samples (12 from minced beef and 2 from liver) were obtained after cold enrichment at $4^{\circ} \mathrm{C}$ for $2-8$ weeks, while only $(8 / 22)$ samples were obtained after enrichment for $48 \mathrm{~h}$ at $30^{\circ} \mathrm{C}$. These results substantiate what have been reported by Hayes et.al. (1986) and Johnson et.al., (1990), they reported that the best method for detecting Listeria was cold enrichment followed by surface plating on selective media. Quinn et al. (1994) demonstrated that L. monocytogenses is one of the few pathogenic bacteria able to grow and multiply under refrigeration temperature, and this psychrotrophic nature of Listeria classes it as a very dangerous foodborne pathogen especially during the cold storage of food (Doyle, 1988 and Johnson et al., 1990).

The pathogenicity of isolated strains of L.monocytogenes in this work induced $100 \%$ mortality at 2-4 day post $\mathrm{I} / \mathrm{P}$ inoculation. On P.M examination haemorrhagic foci in liver, spleen and brain were observed. The organism was recovered from spleen, liver and brain of all dead mice. These results were compatible with those reported by Marco et al. (1992).

The average number of CFU/g of L.monocytogenes were $5.2 \mathrm{X}$ $10^{4}$ and $1.6 \times 10^{3}$ for both positive samples of the minced beef and liver respectively. These findings agree with that reported by Grau and Vanderlinde, (1992) in corned beef. But this number is very high if compared by the standard recorded by Netten et al. (1991). The authors reported that for public health reasons, a standard has been suggested enforcing the absence of L.moncyrogenes in meat and meat products.

This study confirms the view of L.monocytogenes being a frequent contaminant of meat products especially minced beef, so methods should be implemented to prevent this strain from entering and/or multiplying in minced beef e.g cleaning and sanitizing in restaurants should be adequate, water used should be free from this pathogen, and handling the final product just before marketing should occur in an area far away where raw materials are brought and not by the same raw material handlers. 


\section{REFERENCES}

Breer, C. and Schopfer,k. (1988): Listeria and food. Lancet. ii: 1022.

Doyle, M.P. (1988): Effect of environmental and processing conditions on Listeria monocytogenes. Food Technology 42,169-171.

El-Gazzar, M.M.M and Sallam, Kh.I.A. (1997): Occurrence of Listeria monocytogenes and other Listeria spp. in meat products. Alex. J.Vet Sci., 13 (4) 415:421.

Gitter, M., Bradley, R., and Blampied, P.H. (1980): Listeria monocytogenes infection in bovine mastitis. Vet. Rec. 107:390393.

Gracey, J.F. and Collins, D.S. (1992): Meat Hygiene. 9th Ed. Bailliere Tindall.

Grau, F.H. and Vanderlinde, P.B. (1992): occurrence, number, and growth of Listeria monocytogenes on some vaccum-packaged processed meats. J.Food Prot. 55: 4-7.

Hayes, P.S., Feeley, I.C., Graves, G.W, and Fleming, D.W. (1986): Isolation of Listeria monocytogenes from raw milk. Appl. Environ. Microbiol. 51: 438-440.

Höhne, K., Loose, B. and Seeliger,H.P. (1975): Recent Findings of Listeria monocytogenes in slaughter animals of Togo. pp.127130 in M.Woodbine (ed.) Problems of Listeriosis. Leicester university Press, Leicester, England.

Hyslop, N.G. (1974): Epidemiologic and immunologic factors in Listeriosis pp. 94-103 in M.Woodbine (ed) Problems of Listeriosis- Leicester university Press, Surrey, U.K.

ICMSF. (1996): Microorganisms in Foods, Microbiological specification of food pathogenes. Published by Blackie Academic and Professionl an imprint of Cbapman \& Hall- London.

Johnson, J.L., Doyle, M.P., and Cassens, R.G. (1988): Survival of Listeria monocytogenes in ground beef. International Journal of food Microbiology 6:243-247.

Johnson, J.L., Doyle, M.P. and Cassens, R.G. (1990): Listeria monocytogenes and other Listeria spp. in meat and meat products. Areview. J. Food Prot., 53:81-91.

Kerr, K.G., Brikenhand, D., Seale, K.M. and Hawkey, P.M (1993):

Prevalence of Listeira spp. on the hands of food workers. J.

Food prot. 56(6): 525-527. 
Lowry, P.D and Tiong, I. (1988): The incidence of Listeria monocytogenes in meat and meat products: Factors affecting distribution pp 528-530. In Proc. 34th Int. Congress Meat Sci. Technol. Brisbana, Australia.

Luppi, A., Bucci, G., Maini, P.and Rocourt .J. (1988): Ecological survey of Listeria in the Ferrara area (Northren Italy) Zbl. Bakteriol. Mikrobiol. Hyg. A 269:266-275.

Marco, A.; Domingo, M.; prots, N., Alimira. J., Briones., V, and Dominguez, L.(1992): Differences in Pathogenicity between L.monocytogenes and L.ivanovii after I/P and subcut. incoulation. The 11th International symposium on problems of Listerosis, Eigtveds pakhus Copenhegen 11-14 may.

Netten, P.V.; Boer, E. and Jansen, J.T (1991): The occurrence and fate of Listeria monocytogenes in meat and meat products: a legal consideration [Poster] Food policy trends in Europe Nutrition, technology analysis and Safety P.203.

Odegaard, B, Grelland, B. and Henriksen, D. (1952): A case of Listeria infenction in man, transmitted from sheep. Acta Med. Scand. CXLII.231-238.

Quinn, P.J.; Carter, M.E., Markey, B.K. and Carter, G.R (1994): Clinical veterinary microbiology. Walf- Virginia-U.S.A.

Ryser, L.T, Marth, E.H, and Doyle, M.P (1985): Survival of L. monocytogenes during manufacture and storage of Cottoge cheese. J. Food Prot. 48:746-750.

Seeliger, H.P. and Jones, D. (1986): Genus Listeria . pp.1235-1245 in P.H.A Sneath N.S. Main, M.E. Sharpe and J.G Holt (eds) Bergey, manual of systematic bacteriol. Vol. 2 williams and wilkins, Boltimore MD.

Temper. K. (1961): ber das Vorkommen von L.monocytognens bei not Krangeschlachteten Haustieren. Archiv fur Lebensmittelhyg. 12:1-4.

WHO (1988): Report of the WHO infromal working group on foodborne Listeriosis Geneva 15-19 February 1988 (WHO 16HE/ FOS/ 88.5) World Health Organisation. 